\title{
家畜管理に関する生態学的研究について
}

\author{
三 村 耕
}

(広島大学水育産学部畜産学教室)

\section{Ecological Studies on the Farm Animal Management}

\section{Ko Mimura}

(Department of Animal Husbandry, Faculty of Fisheries \& Animal Husbandry, Hiroshima University)

1. 家蓄管理学と生態学

家畜管理学はいうまでもなく，畜産学を支える柱の 1 つをなすあのであるが，わが国の最も指導的意見(

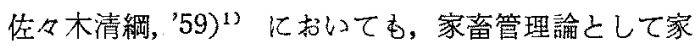
畜環境衛生論および畜舎と設菕器具の項目をあげ，家 畜生物学的分科の1つをなすをしている亿過ぎない。 世界拉上びわが国の家畜管理学の学問的水準が，家音 育種学その他之肩を並ぶるに至つていない現状を考虑 してのことであるう。

しかし加唐 ('51) 2) が指摘した如く, 家畜管理学は 衛生的環境や畜会の建築技術に終るぶきものではむち

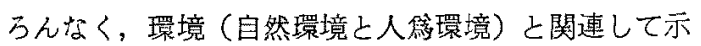
される家畜の生龍（個生態学的な意味ばかりでなく, 集団的・相互関連的内容をふくむ一後者は今後上り 重要である）の研究を基礎として，飼育者の家音への 合理的仂き加け方を研究する学問である. 彷つて，る の中心の基礎学は生態学であり, 生理学 (環境生理学 environmental physiology) であり，そして，てんに ちまでの成果にはほとんどみるがきすのはないが，家 畜心理学すまたその重要な基礎となるべきものと考沉 る。

ところで, 生態学については, こんにちも尚湿沌と して，方法論的論争が緬行られており，“人間科学に 招ける広義の社会学 social science K対比される分野 としての生物科学に㕲ける生態学”之いう社会学的方 向 (沼田, '56) ${ }^{8)}$ が強く主張される一方, HAECKEL (1866) 以来の伝統である生態学を関係生理学 Bezichungsphsiologie 01 分科とみなす，好功る生理 生態学を主張する考えも多い，後者は，沼田・今西ら

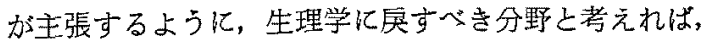
とれを環境学的生態学とよぶよりは㻴境生理学 ecological physiology よよふ力が正しいであるう。

家畜管理学の立場加らすれば，家音集団それ自身の 社会学的考察屯大切ではあるが, 人第的・自然的環境
とこれに対する家畜の反応，いわゆる stimulus-response mechanism (HOAR, '56) ${ }^{4}$ 在物理化学的飞追求 することむ極好重要であり，乙れは環境生理学その あのである。

以上の理由汃ら，筆者は家畜管理学の中心的な基整 学は生態学・生理学书よび心理学としたのであるが， 本槁比いては，家畜の生理生態学的研究を，一灾常 識的に生態学の1 分野とみなすととにし，乙の種の研 究をふくめて，家䱜管理学の基礎としての角度加ら， 世界扰上びわが国の生態学的研究について述べること 比する。

2. 放牧生態江関守石研究

1748年スウエーデンの CAROLUS LINNAEUS は友人 への手紙の中で，次のように書き送つている.

'This summer I continued my investigations as to which plants are consumed by cattle, which are ignored, and which are avoided; this work, in my opinion, is of fundamental improtance both for private owners of livestock and for animal husbandry as a whole.'

いわゆる草地農学があくまであ畜産を対鱼とする限 り，造成された草地を，家畜にどの上うに効果的に利 用させる加ということは，草地農学の楯の半面をなす あのであらう.しかし LINNAEUS の手綎に示されて 《るように，そ机は長い間顧られなかつた分野でああ つたようである，TRIBE ('55) ${ }^{53}$ とると，英国ではこ の種の研究は，まず agronomistにより始められた。

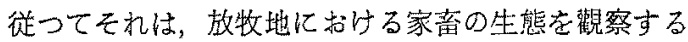
ことから始められた。

TRIBE は家蓄の放牧生態の定型を次の上うに示して いる.すなわち，採食時間は昼間約65\%夜間約 $35 \%$ で

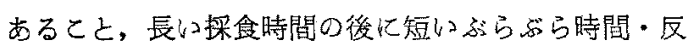
媸時間・休息時間が続き再び長い探食時間化入るこ上， この順序は事情のない限り変らないとと，区瑟は大体 
日没直後座りこんだ態勢で行うことが多いこと，乳 牛・めん羊が休息時济眠るととは疑問で，少くもその 時間は極めて短いととなどである。

との定型はも5万ん各種の要因に上つて動摇する。 TRIBE は HANCOCK('50) ${ }^{6)}$ な゙の成果を引用して, 主 として遺伝的差晎に基く個体性を問題にしている。採 食能力江関保する下顎の巾・長さ，草を選択する能力 ・反钩速度・歩行能力などてある.

放牧地の草生状態む重要な要因で，良好な場合は採 传時間が短いが，貧弱場合は長い(ATKESON ら， '427); SMITH, '5997). HaNCOCK (50) は rt/gt 值を提 唱しているか，rt は反唯時間gt は放呚時間で草生の不 良なときはこの値が高い。貲では補食させる乾草や濃 厚飼料によつて罢るようである(ChAmBERS, '59) ${ }^{9}$.

湿度の影響は小さいようで尔る (MLLER\& FRYE， '56) ${ }^{103}$ が，気温の影響は大きく，高温環境では夜間の 放牧時間が急化大きなり (SEATH \& MILLER, '47"1); HARDISON ら, '56'2) , その臨界温度注 BENNIE ('56) 132による上 $27^{\circ} \mathrm{C}$ とられる。

最近の研究動向で注目すふささとは, 为1は, 觀察 万法隹余りにも主觀的要素の多く，その上不統一なと とに対する批判に応えて，自動記録装置の改良が進め られているととであるう(GORDON \& TRIBE, '52 14); CANAWAYら, '55 ${ }^{15)}$; BURTON \& CASTLE, ' $\left.55^{16)}\right)$. 事

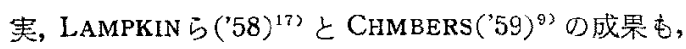
その観察方法が統一されていれ姑，わたくし達はより 有効代検討できるととであろう，为2 2 亿は，放牧家蓄 が採取した草の量・質を定量的㳊测定する研究や，放 牧家畜を器境生理学的に追求する方向が急激に增加し ていることで, 従来の觀察生態学からの必然的な発展 と考えられる。

最後に, FAOの低開発地域の畜産開発に伴い, 生 熊学的研究方法が RHOAD, PHILLIPS らを中心として 組織的に用いられていることを挙げなくてはならない。 クリマトクラフ・ヒッテルクラフ・カルトクラフなど の音虚的応用がをの效果を挙将 (WRIGHT, '54 ${ }^{18)}$; PHILLIPS, '58 $\left.{ }^{19}\right)$ ), 熱帯・理㷫带に怙けるヨーロツパ 牛やその雑種の生態学的觀察も非常に多くなつている (LAMPKIN 弓, '58 '7); MAHADEVAN, '56'02).

3. 家畜の性生㮩问関する研究

人工授精の普及に上つて，家畜の性生態関する研 究は著しく活潑になつてきた。 WALTON (’55) 21)は各 牡畜の性生態の特徽を, その性器の構造の解剖学的所 見加ら綜説すると共に, 性生態を支配する中心部の所 在てついては, BEACH, BATTEllI, GUNN から始ま
る整気射精器に上る成果の上に立つて，自律神経系の 仂きによることを明らかにしている。

とんにち，乙の神経系の仂きやそのホルモンとの関 係など，末知の部分が余りに屯多いか，電気射精に何 故リズミカルな刺激が必要か，擬牝台・台牛はどのよ うに壮畜の性生㦔飞影響するかなど，実際的な問題と 関連して, 生態学的研究の意義も大きい.

高温 (ChomiaK ら, '54 22 ; Glover, '56 28 ; Foote 万, '57 $\left.7^{24}\right)$ ), 低温 (DUTT \& BUSH, '55 $5^{25)}$ ), 光線 (LAKE 8. WOOD-GUSH, '万6-28), 土地の高度(KAMALJAN, '58

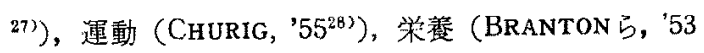

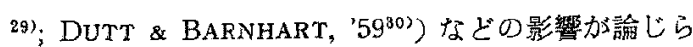
れている，牡と牝の同居は繁殖成績にプラスかマイナ

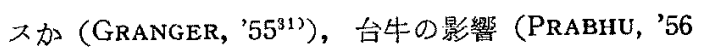
${ }^{32}$; ALMQUIST \& HALE, '56 ${ }^{83)}$ ) 屯論議され，女ん羊

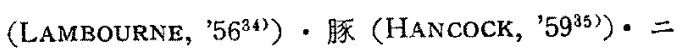
ワトリ (Williams \& MCGibBon, '57 ${ }^{86)}$ の興味樑い 性生態屯報告きれている。

4. 家畜のその他の生驡阙する研究

家畜の一日の行動を詳細倠㓋察し記録する努力は， こん占もなお重要である。この種の研究は授乳・厯 眠・横卧・反努加ら始まり排䔬排尿化至るまでの地道

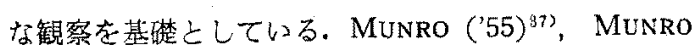
\& INKSON (57) ${ }^{38)}$, BARNICOATら (56) ${ }^{39)}$, OHOTINA $(58)^{402}$, TERNOVENKo ('58) ${ }^{41}$, 丹羽 $5(' 51)^{42)}$. CARTON $\left.ら(53)^{43}\right)$ BARBer $ら(' 55)^{44)}$; LUCAS $ら$

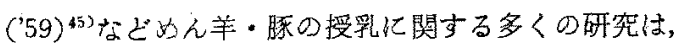
その人工乳和よび自動給飼器の発達のための基礎とし で重要な意義を有する.

飼料の昧・臭・形・色それそれれが，家畜の督好性に 作用するが，これを生態学的ならびに感党生理学的に 追求した研究方多く発表されるようになつた。

BELL (59) ${ }^{46)}$ は家率それぞれの昧党の特性を試験し， TRIBE \& GORDON (50) 57 は的九羊の色覚はほ上んご

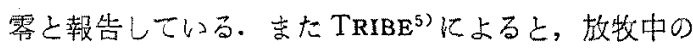

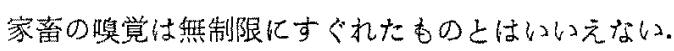

家畜が栄養上の必要から飼料の選択ができるが゙う かは，非常に興味滐い問題であるが，GORDON\& TRI-

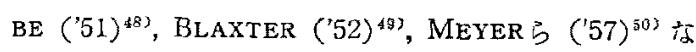
どの報告から考えると，その能力は相当制限されたも ののようにみえる.

乳牛の睡眠時間之乳量の関係 (SJUSJUKIN, ${ }^{5} 57$ ) ${ }^{\text {51) }}$ は鎮静剂の家畜への応用之む関連して與味哚い。

5. 家畜の環境生理学的研究

STAFFE ('48) ${ }^{52)}$, FINDLAY \& BEAKLEY ('54) ${ }^{53)}$ 


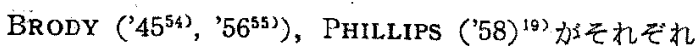
すぐれた綜説を発表しているが，FINDLAY の述ふて いるよ5に、乙の電の研究は，最近はなや加開拓さ れつつあり，戦後の畜産学界におりる新しい傾向亡い うことかできよう。

わだくし達は，この傾问の生じた社会的背景として 次の事情を指摘することがでる.

1) アジア・アフリカ・中米などの新與国が，民族 的意識に目覚めて立上り，農業の面では，自立農業を 目指し畜産の強化をとり上げた。しかし熱帶ないし州 熱带圈という事情の下では，ヨーロツパ音虚と络異な る熱地畜産に関係する技術を組絨的に研究する必要が 生じ:FAOがその技術援助に乗り出した (PHILLIPS, '4856), '505i); RHOAD, '55 $5^{58)}$; LEE-PHILLIPS-RICHTER

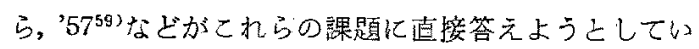
る代表的ら労作である).こてでの主な課題は，家畜の 体温調節機能と生産能力との関係，熱堆的家畜の弯種， 熱地に和ける家畜の管理などである.同様に，極寒地 八の人類の進出は，寒地蓄産の新らしい課題を生じつ つ市.

2) ミチユーリン・ルイセンコ遗伝学に代表される, 環境を重視するソ連の畜産および畜産学の影響が举け

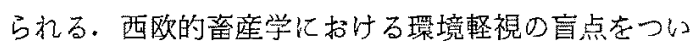
た，廷的畜産学の考え方が研究省の反省を促した功

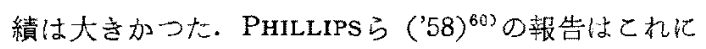
対する直接の反応とみることができよう.

体温調節機能について BRODY一派はをの psychroenergetics laboratory 飞より, また FINDLAY 派はその psychrometric room により，それでれすぐ れた系統的研究を行なつている。これによると，水分 蒸散譏構は，家畜では最す論議される部分と考えられ， 不感蒸泄この他をふくめて，高温環境時の体熱放散に 果す役割の大きいことが指摘されている.

発汗機能の究明のため，先ず开線の組緇学的研究が 行なわれ (YAMANE \& ONO, '36 ${ }^{61}$; FINDLAY \& YANG, '4862); GOODALL \& YANG, '5263); YANG, '5264); MY-

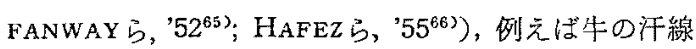
はアポクリン型で，これに連絡する血管組織の䨘弱な こしが明らかにされた。 そして次为に, 高温高湿度下

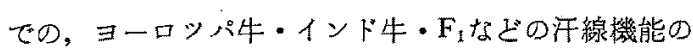

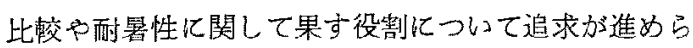

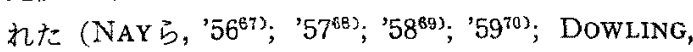
'58 $8^{71)}$; TANEJA, '58 $\left.8^{72)}\right)$. 一般にインド牛系が, 汗腺の 太さ密度にすぐれているとしているが，FERGUSON \& DowLING (55) ${ }^{73)}$ は汗腺の容積に差がなく，その譏能
に差があると主張している。

しかし BRODY ${ }^{553}$ は，イント牳の単位面啮当りの水

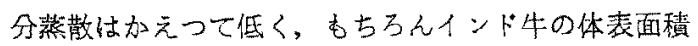

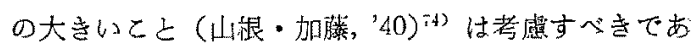

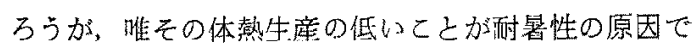

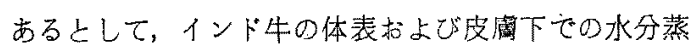
散の高いこ上主張するFINDLAY bの見解之対立し

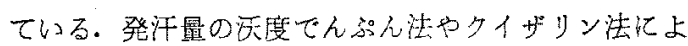
る測定の园知なととは籍者屯経駘しておりすがれた 測定法が考案されれば，乙の䦗題の解沠を容易にする であるう. 最近塩化コバルト法(BERMAN, 57$)^{75)}$, 力 プセル法 (TANEJA) ${ }^{72}$ 方溌表さ机ている。

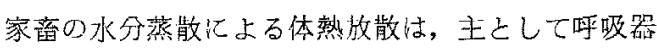

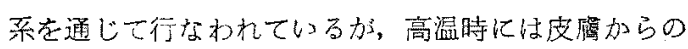

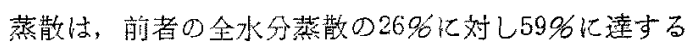

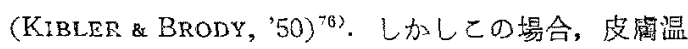
の急激な上景の事垁は，単化体表面加らの水分蒸散作

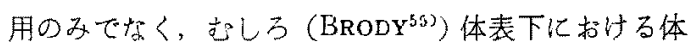
熱放散機柾に往意が向けられるに至つた。

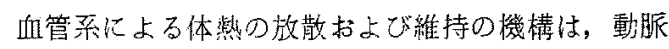
一静脈 vanae comites 比々る熱交換作用や血流変化儿 よる仂孚など代表されているが，乙扎関運して皮 膚温测定の重要性加強調されている(MYFANWAY, '54 (i); GOODALL, '54:3); BEAKLEY' \& FNADLAY, '55'79);

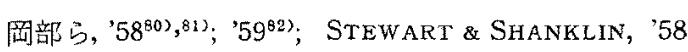

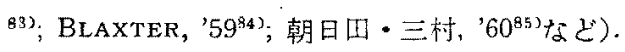

その他体温調節機能と, ホルモンの哭係 (GRAF \&

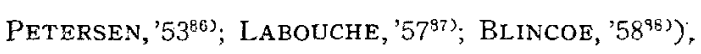

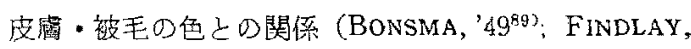

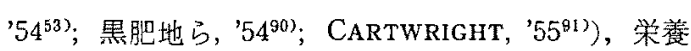
亡の関係 (ROBINSON \& LEE, '47) ${ }^{023}$ ，血液成分上の関

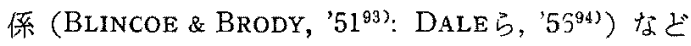
各方面に研究犬゙進められている.

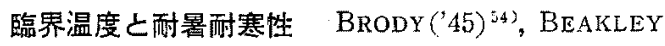

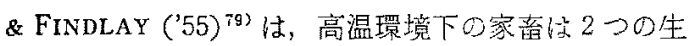

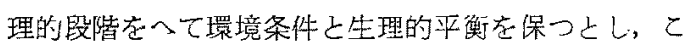
の为 2 の体熱生産抑制の段階は，生座的には体温調節

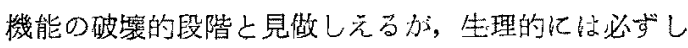
まそちいいきれないと述へている。

このように，体温調節譏能に関する臨界温度をごこ 隹求める加は小捈討を要するが，一般にはその物理

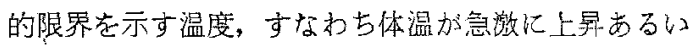
は下降を示す温度としている。

BRODYは， ヨーロツパ制の奵適温度は $0^{\circ} \sim 16^{\circ} \mathrm{C}$, 臨

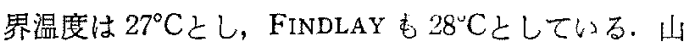


根ら('40)星) はホルスタイン種は $28^{\circ} \mathrm{C}$ とている。

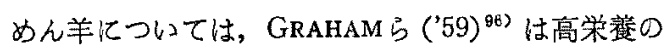
ぬん羊で $24^{\circ} \sim 27^{\circ} \mathrm{C}$, 三村('56) $)^{97)}$ ，朝日田・三村 ('58) 98) は2 $25^{\circ} \mathrm{C}$ と主張している.

耐署性・耐寒性はいうまであなく体温調節の強弱に 関係するが，必ずしも同一の基砣で諭じられている訳 ではなく（岡本，'56) ${ }^{992}$ ，例えば RHOAD ('44) 100) は 体温を基礎とし, BENEZRA ('54) ${ }^{101}$, VERNON弓 ('59) 102)はこ机呼吸数を加味している.

牛・めん羊の各品種の耐暑対寒性の比較は，枚挙に いとまがない程多く発表され，乳牛では，シャージー 種はホルスタイン種に比䩙して耐暑性にまさり酎寒性 に劣ること，インド牛於よびその倠種がヨーロツパ牛 より耐暑性にまさることは，こんにちでは常識という ことができよう。

耐暑性に比較すると，耐寒性の研究は非常に少いが， AMSCHLER ('57) $)^{108)}$, RAKo \& DUMANOVSKY ('58) 1047 らに上つてみても，犯たくし達の乳牛・めん羊の多く は, 耐寒性に富んでいることが理解される。

光周期 BRODY, FINDLAYは日光をエネルギー上 して捉えたが，てのリスミカルな変化すな和苦光周期 と繁殖の秘密化挑戦して, め九羊・山羊・馬の䆘節外 繁殖に成功した功績は BISSONNETTE，MARSHALL, HAMMOND, BURKHARDT, YEATES に帰せられる (YeATES, '54) ${ }^{105)}$. わが国であ山羊 (吉岡)，め九羊 (三村)，馬（西川）成功している.

光線の二ワトリへの影響仗, 点灯飼育の実用的立場 加らの研究が多く発表されている(石橋, '50106); HUTCHINSON, '56 ${ }^{1072}$; WILSON \& ABPLANALP, '56 ${ }^{103)}$;

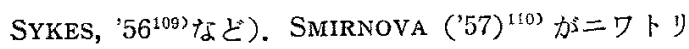
で, Meljukov ('56) $)^{110)}$, GrigorJeVA ('57) ${ }^{112)}$ が乳 牛でそれぞれ紫外線の効果を述べており，ソ連におけ る倾向が認的らて面白い.

光周期已生産能力については, 羊毛生産に短日期が マイナスに仂くとのCOOP('53) ${ }^{113)}$ 亿対し, WILDMAN

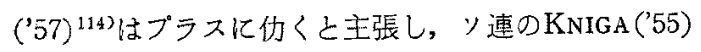
115）は乳牛以暗空処理をすると、乳脂肪率が減少する と報告している.

この種の研究で注意すべきことは, 人工光線と暗 室爸理により，長期精密実験の結果加方光周期の影響 を論ずるものが多くなつているととで，今後に䔁期的 な成果が期待できるのではなからか。

その他 YEATES ('55, '57) ${ }^{116)}$ の牛の被毛への影響な ども発表されている.

開放式畜舎について

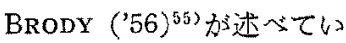

るように，改良家畜の多くが極めて北方的体制を有す る事実が，環境生理学的に明ら加になるにつれ，畜舎 の構造，日常管理などに再検討の必要が痛感されてき た. HEIZER 弓 ('53) ${ }^{117}$ の loose housing barns, WEBER ('54) ${ }^{118)}$, COMBERG $5(' 56, ' 57, ' 58)^{111)}$ ○ Offenstall の研究などは，之の当非は別として, 戦後 の注日す心゙き研究化数えることができるであろう。

やや的度は異るが, HIBBS ら ('53, '56) ${ }^{120), 121), ~ M U-~}$ RLEY \& CULVAhouse ('58) ${ }^{122)} \odot$ high roughage system む, 単に消化生理の立場からのみ問題にすべき あのではない。

管理の影赔について BRODY・RAGSDALE一派の 一連の系統的な研究が, 単なる乳牛の日蔳の研究に留 るすのでないととは前述したが, 換気・灌水・泠房・ 日䔖の乳牛への影響 (ITTNERら, '55, '57 ${ }^{123)}$; PATRICK, '58 ${ }^{124)}$ など), 领水について(HARBINら, '58 ${ }^{125) ; ~ B A I L E Y ~}$ \& BROSTER, '58 ${ }^{126)}$ ), 二ワトリに対する換気打よび防

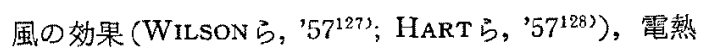

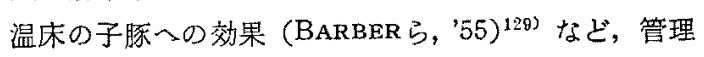
の家童への影響を環境生理学的に追求する研究も多く みられるようになつた。

乳房のマッサージ温包処理坛どが, ソ連の学者に よつて唱導されて以來，こんにちもなおての種の研究 を多くみることができる。

機械控筧䎲伴う管理学的問題李多いが, わが国では,

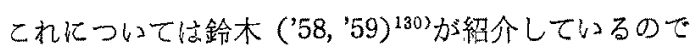
省略する.

6. わが国比りる生態学的研究

戦前のわが国は，ての種の研究では不毛の地であり， その研究成果は数えるに足りない状態であった, 山根 を中心之する耐暑性の研究 (山根ら, $40^{n 5}$ ); 山根・加 藤, '4074); 葛野・寺田, ' 41 , '43 $3^{131)}$ ), 茾口・三田村ら の乳牛への季節の影響その他（井口・三田村, '29 ${ }^{132}$,

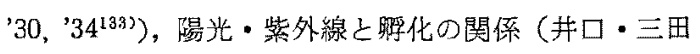

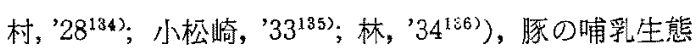
(成松・原, '34) ${ }^{1377}$, 放牧招よご放牧地（園田, '32138); 大迫, ' $37^{1397}$; 岩谷・今, ' $40^{140)}$; 畜試長野交場, ' $40^{141)}$ ), 季節上羊毛(岡田・大野, ' $40^{142)}$; 慶州種羊場, ' $44^{(43)}$ ), め九羊の生態について (北海道宁種羊場, ' 38 ) ${ }^{144)}$, 馬の

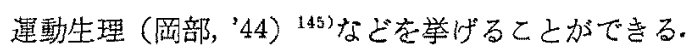

戦後は, 前述の社会的背景のほ加, 更渀地農業の 導入が，乙の種の研究の大きな刺激剂となつて，各方 面施たつて活潑な研究が進められていることは喜ば Li.

本年度の学会に执いて李, 環境要因(三村・朝日田)， 
馬の恐怖性 (石崎・本沢), 放牧牛の生態 (青木), 乳 牛の而暑性 (野田・西山・岡本), 機械控乳(砱木), 家要の喰粪 (平林), 労役生理 (吉田・辰已引)などの 報告を聞くことができた。

以下に，主な研究動向について簡単にふれてみたい (以下文献省略).

西南暖地の蓄産が問題になるにつれて, 釈牛・䀠・ 和牛・めん羊の耐暑性㧍上びその管理が，新たに検討 されている（九大・鹿大・九州農試・中国農試・広大 など). 北海道などに怙ける酎寒性の研究も, 今後当 然行なわれるべきすのであるう。

環境生理学的研究に拈いて注意すべきととは，常に 温湿度調節室に上る精密試験により，野外試験の結果 を補足訂正する必要の市ることで，光周期関する試 験についても同様なと々がいる，前述の上うと諸外国 で结，2 年連続調整された人工光線下て武験している 成果素発表导机ている. 要因分析のため、筆者らが季 節外生産羊を利用した理由す, 要因相互の影響を除去 する目的からであった。

放牧生態拈よびその環境生理学的研究 (北大・島根 農大・中国農試・北海道農試)，労役生理の面加らで はあるが運動の環境生理学的意義を明らかにしつつあ る東大・京大・農技研などの研究屯をの発展を期待し たい.

環境之成長，遺伝上環境，馬の心理の研究（関東東 山農試)，機械㵠乳の吥究(鈴木) などは，わが国で 最あ不足していた分野であつて，てれ之真正面にとり 組んでいる研究者達の趾斗を祈りたい。扔, わが国 家畜生熊学の歴史の中では, その先達の 1 人として川 瀬の諸労作を忘れることはできないであるう。

しかしてのようにみて来ると, 草地農学の音産的側 面の研究の㑈然手薄なととに気がつくであ万う. 英国 その他で，先ずAgronomist からとれに参加したから といつて，かが国もまた同じ経過を辿る必要は毛頭な

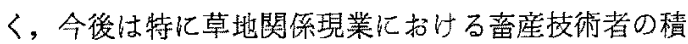
極的参加加望まれる.

以上紙数の関係で, 多数の研究報告の紹介省略し たが, 別の機会をえて，特に環境生理学の分野につい ての欠を補うつもりである，最捘に文献䒯集その他に 協力願つた朝日田康司氏に深謝したい。

\section{文献}

1）佐々木清綱、畜産学々畜産技術. 養賢堂版畜 産大系为 1 編, 1959.

2) 加唐勝三 畜研, $5: 375,1951$.
3）沼田 真 生態学方法論, 3 版. 東京, 古今書 院, 1956.

4) HoAr, W. S. Environmental Physiology of Animals. New York, Scholar's Library, 1956.

5) Tribe, D.E. Progress in the Physiology of Farm Animals $2: 585 \sim 602$. London, Butterworths Sci. Pub., 1955.

6) НаNсоск, J. N. Z. J. sci. Tech., Sec. A. $32: 22,1950$. cited by Tribe ('55).

7) Atkeson, F. W. et al. J. Dairy Sci., 25 : 779, 1942.

8) Sмith, C. A. J. Agric. Sci., 52. 369, 1959.

9) Chambers, D. T. J. Agric. Sci., 53:417, 1959.

10) Miller, G. D. \& J. B. Jr. Frye J. Dairy Sci., $39: 1730,1956$.

11) Seath, D. M. \& G. D. Miller ibid., 30: 921, 1947.

12) Hardison, W. A. et al. ibid., $39: 1735$, 1956.

13) Bennie, J. G. S. Anim. Breed. Abst., 25 No. 578, 1956.

14) Gordon, J G. \& D. E. TRIBE Brit. J. Nutrit., 6: 89, 1952.

15) CANawaY, R. J. et al. Electron Engng,, March 1955: 4; Anim. Breed. Abst., 24,No.48, 1956.

16) Burton, H. \& M. E. Castle J. Dairy Sci., $17: 229,1955$.

17) Lampkin, G. H. et al. J. Agric. Sci., 50: $211,1958$.

18) Wright, N.C. Progress in the Physiology of Farm Animals $1: 191 \sim 251$. London, Butterworths Sci. Pub., 1954.

19) Phillips, R.W. Handbuch der Tierzüchtung 1:427 447. Hamburg u. Berlin, Paul Parey, 1958.

20) Mahadevan, P. Dairy Cattle Breeding in the Tropics. England, Commonwealth Agric. Bureaux, 1956.

21) Walton, A. Progress in the Physiology of Farm Animals 2:603 616. London, Butterworths Sci. Pub., 1955.

22) Сномiaк, M. et al. Ann. Univ. M. CurieSklowska, D. D., $9: 223$; Anim. Breed. Abst., 24, No. 1878, 1954. 
23) Glover, T. D. J. Endocrin., 13:235;

Anim. Breed. Abst., 25, No.230, 1956.

24) Foote, W. C. et al. J. Anim. Sci., 16 : $144,1957$.

25) DutT, R. H. \& L. F. BusH ibid, 14:885, 1955.

26) LAKE, P.E. \& D.G.M. Wood-Gush Nature, $178: 853,1956$.

27) Kamaljan, V. S. Anim. Breed. Abst. 28, No.322, 1958.

28) Churig, J. et al. Csl. Biol., 4: 158; Anim. Breed. Abst., 25, No.890, 1955.

29) Branton, C. et al. J. Dairy Sci., $36: 199$, 1953.

30) Dutt, R.H. \& C. E. Barnhart J. Anim. Sci., 18:3, 1959.

31) Granger, W. Aust. vet. J, 31:138, 1955.

32) PrabHU, S. S. Indian J. Vet. Sci, $26: 21$;

Anim. Breed. Abst., 25, No.158, 1956.

33) Almquist, J. O. \& E. B. Hale Anim.

Breed. Abst., 25, No.684, 1956.

34) Lambourne, L. J. Dept. Agric. N. Z. pp. $16 \sim 20,1956$.

35) Hancock, J. L. J. Agric. Sci., 53:313, 1959.

36) Williams, C. \& W. H. MCGibBon Poult. Sci., $36: 30,1957$.

37) MUnro, J. J. Agric. Sci., 46: 131, 1955.

38) MUnko, J. \& R.H. E. InKson, ibid., 49 : $169,1957$.

39) BARNicoAt, C.R. et al. ibid, 48:9, 1956.

40) Ohotina, D.N. Ovcevodstvo, 4:19; Anim. Breed. Abst., 26, No.1798, 1958.

41) Ternovenko, N. M. ibid., 4:24; ibid, 26, No.1408, 1958

42) 丹羽太左衛門他農技研報 $\mathrm{G},(1): 135,1951$.

43) Carton, D. V. et al. J. Anim. Sci., 12: $62,1953$.

44) Barber, R. S. et al. J. Agric. Sci, 46:97, 1955.

45) LucAs, I. A. M. et al. ibid., 53:125, 1959.

46) Bell, F. R. ibid., 52: 125, 1959.

47) TRIBE D. E. \& J. G. GORdoN ibid., 39 : $313,1950$.

48) GCRDON, J. G. \& D. E. TrIBE ibid,, 41 :
$187,1951$.

49) Blaxter, K. L. Brit. J. Nutrit, 6:110, 1952.

50) Meyer, J. H. et al. J. Anim. Sci, 16:766, 1957.

51) Sjusjukin, V.A. Trud. Mosk Vet. Akad, 20 : 110; Anim. Breed. Abst., 28, No.114, 1957.

52) Staffe, A. Hausiere und Umbelt. Bern; Paul Haupt, 1948.

53) Findlay, J.D.\& W.R. BEAKLEY Progress in the Physiology of Farm Animals 1:252 298. London, Butterworths Sci. Pub., 1954.

54) Brody, S. Bioenergetics and Growth. New York, Reinhold Pub., 1945.

55) _-. J. Dairy Sci, 39:715, 1956.

56) Phillips, R. W. Breeding Livestock adapted to Unfavorable Environments. FAO Agric. Studies No. 1, 1948.

57)

FAO Development Paper

No. 6 \& No. 8,1950

58) RhoAd, A. O, et al. Breeding Beef Cattle for Unfavorable Environments. Austin, Univ. of Texas Press, 1955.

59) Lee, Phillips, Richter et al. Publication of European Association for Animal No. 5. Rome, 1957 .

60) Phillips, R. W. J. Hered., $49: 46,1958$.

61) Yamane, J. \& Y. Ono Mem. Fac. Sci. \&. Agr. Taihoku Imp. Univ., 19, 1936.

62) FIndLAY, J. D. \& S. H. YANG Nature, 161 : $1012,1948$.

63) GoOdall, A.M. \& S. H. YANG J. Agric. Sci., $42: 160,1952$.

64) YANG, S. H. ibid., $42: 156,1952$.

65) MYFanway, A. et al. ibid., 42:159, 1952.

66) HAFEz, E.S.E. et al. ibid., 46:19, 1955.

67) NAY, T. \& R. H. HAYMAN Aust. J. Agric. Res, $7: 482,1956$.

68) —. \& D.F. Dowling ibid, 8:385, 1957.

69) HAYAN, R.H. \& T. NAY ibid., 9:385, 1958.

70) NAY, T. ibid., 10:121, 1959.

71) Dowling, D.F. ibid., 9:579, 1958.

72) Taneja, G. C. J: Agric. Sci., 50:73, 1958.

73) Ferguson, K. A. \& D. F. Dowling Aust. J. Agric. Res., $6: 640,1955$. 
74）山根甚信 - 加藤 浩 熱帯獣医畜産誌 $1: 20$, 1940.

75) Berman, A. Nature, $179: 1256,1957$.

76) KibleR, H.H. \& S. BRODY Res. Bull. Mo. Agric. Exp. Sta. No. 461, 1950.

77) Myfanway, A. et al. J. Agric. Sci., 44 : $1,1954$.

78) Goodall, A. M. cited by FindLAY ${ }^{58}$.

79) Beakley, W. B. \& J. D. Findlay J. Agric. Sci. $45: 339,1955$

80）岡部・杉山・大井日㐬会報, $29: 122,1958$.

81) 大井澄雄・岡部利雄同上, $29: 157,1958$.

82）—— 同上, 30:117, 1959.

83) Stewart, R.E. \& M. D. Shanklin Res.

Bull. Mo. Agric. Exp. Sta, No. 656, 1958.

84) Blax ter, W. J. Agric. Sci, $52: 25,1959$.

85）朝日田康司・三村 耕 日畜会報, $31: 62$, 1960.

86) Graf, G.C. \& W. E. Petersen J. Agric. Sci., $36: 1036,1953$.

87) Labouche, C. C. R. soc. Biol., 151:1171; Anim. Breed. Abst., 26, No.1258, 1957.

88) Buincoe, C. Res. Bull. Mo. Agric. Exp. Sta., No. 649, 1958.

89) Bonsma, J. C. J, Agric. Sci., $39: 204,1949$.

90）黒肥地一郎他 九農試畜試験成績概要， 昭29, 1954.

91) Cartwright, T. C. J. Anim. Sci., 14: 350, 1955.

92) Robinson, K. \& D. H. K. Lee J. Anim. Sci., $6: 182,1947$.

93) Blincoe, C. \& S. Brody Res. Bull. Mo. Agric. Exp. Sta., No. 488, 1951.

94) Dale, H. E. et al ibid, No. 608, 1956.

95）山根甚信 他熱帯獣医蓄産誌, 1:1, 1940

96) Graham, N. McC. et al. J. Agric. Sci., $52: 13,1959$.

97）三村 耕 広大水畜紀要, 1:203, 1956.

98）朝日田康司・三村 耕 日畜会報，29:117, 1958.

99）岡本正幹蓄産学の進歩 pp. 400 409. 東京, 養蜸堂, 1956 .

100) RhoAd, A. O, Tropical Agric. 21:162, 1944. cited by RHOAD ${ }^{583}$.

101) BENEZRA, M. V. 凧本正幹星々よる
102) Vernon, E. H. J. Anim. Sci. 18:91, 1959.

103) Amschler, J.W. Publ. Europ. Ass. Anim. Prod. No. 5 : 193, 1957.

104) Rako, A. \& F. Dumanovsky Züchtungskunde, $30: 225,1958$.

105) Yeates, N. T.M. Progress in the Physiology of Farm Animals 1:363 392. London, Butterworths Sci. Pub., 1954.

106）石橋武㢁蓄会報, $21: 5,1950$.

107) Hutchinson, J. C. D. Nature, $177: 795$, 1956.

108) Wilson, W. O. \& H. Abplanalp Poult. Sci, $35: 532,1956$.

109) Sykes, A.H. J. Agric. Sci, $47: 429,1956$.

110) Smirnova, E. I. Pticevodstvo, $7: 40$;

Anim. Breed. Abst., 25, No.2080, 1957.

111) Meljukov, A. N. Nauka Pered. Opyt. Sel. Hoz., 1956 : 8; Anim. Breed, Abst., 25, No.643, 1956.

112) Grigorjeva, A. Ja. Zivotnovodstvo, 19: 79; Anim. Breed. Abst., 26, No.663, 1957.

113) Coop, I. E. J. Agric. Sci., 43: 456, 1953.

114) Wildman, A. B. Nature, $180: 296,1957$.

115) KnIGA, M. I. Anim. Breed. Abst., 25, No. ô47, 1955 .

116) Yeates, N.T.M. Aust. J. Agric. Res., 6: $891 \& 8: 733,1955 \& 1957$.

117) Heizer, E. E. et al. J. Dairy Sci., $36: 281$, 1953.

118) Weber, F. Z. Tierz. Zuchtgsbiol, 64:1, 1954.

119) Comberg, G. \& M. Koallick Tierzucht., $10: 198 \& 11: 73,109,1956$ \& 1957.

__ \& K. H. VOLgTLÄNDER Z. Tierz.

Zuchtgsbiol., $71: 164,1958$.

120) HibBs, J. W. et al. J. Dairy Sci., $36: 717$, 1953.

121) Conrad, H. R. \& J. W. Hibbs ibid., 39 : 1170, 1956.

122) MURLey, W.R. \& E.W. Culvahouse ibid., $41: 977,1958$.

123) IttneR, N. R. et al. J. Anim. Sci., 14: 818 \& $16: 732,1955$ \& 1957.

124) Patrick, T. E. et al. J. Dairy Sci., 41 : 344, 1958. 


$$
\text { 三 村 }
$$

125) Harbin, R. et al. ibid., $41: 1621,1958$.

126) Bailey, G. L. \& W. H. Broster J. Agric. Sci., $50: 8,1958$.

127) Wilson, W. O. et al. Poult. Sci, $36: 978$, 1957.

128) HART, S. A. et al. ibid., 36:662, 1957.

129) Barber, R. S. et al. J. Agric. Sci, 46: $31,1955$.

130）鈴木健二 畜斫， $12: 1507 \& 13: 1247,1958$ \& 1959.

131) 莫野浅太郎・寺田日吉熱带獣医畜産誌，2： $1 \& 2: 159,1941 \& 1943$.

132）井口賢三・三田村硉太郎 $184,1929$.

133）井口賢三 他北大農附属農場特别郝， 2 号 \& 5 号, 1930 \& 1934 .
134）并口蜸三・三田村健太郎“札县譨林学会報, 27 号, 1928.

135）小松崎万次郎日畜会報，6:171，1933.

136) 林 交平 同上, $7: 255,1934$.

137）成松静雄・原 実 同上, 7:20, 1934.

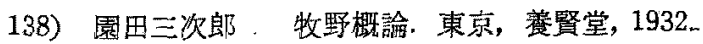

139）大迫元婎 本邦原野汇関する研究，與林会， 1937.

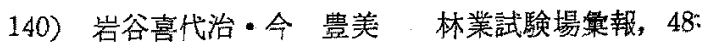
号, 1940 .

141）畜産試験場長野支場畜試年報，6 号，1940.

142）圆田重治・大野末松農動試験場研究時報,

34 믁, 1940.

143）朝鮮総督府慶州種羊場 日音会報， 16:156,.. 1944.

144）北海道庁種羊場緬羊靠報, $12,1938$.

145）岡部利雄・杉山豊一 日獣医誌, 6:1.1944。 